\title{
Solimán el Magnífico y Roxolana. EL PODER DEL TURCO EN LA CULTURA VISUAL Y ESCRITA DE OCCIDENTE
}

\author{
Cristina Igual Castelló \\ Universitat Jaume I
}

RESUMEN: El artículo pretende analizar la imagen de poder creada en Occidente alrededor de Solimán el Magnífico y su esposa Roxolana. Bajo el deseo de entender la magnificencia de ambos sultanes, el escrito se ha estructurado en torno a tres aspectos fundamentales. El primero de ellos se ha centrado en la relevancia de Solimán y su imperio, para hallar la explicación de su capacidad militar y la razón de ser considerado una amenaza para el mundo occidental. Seguidamente se ha presentado el palacio como expresión arquitectónica de poder, además de ser el espacio donde se situaba el harén. Ello ha conducido a reflexionar sobre el papel de la mujer en la sociedad turca y se ha profundizado en la figura de Roxolana, la favorita del Gran Turco. Así pues, se han estudiado ejemplos de las crónicas, la literatura de viajes, los libros de indumentaria, los grabados y las pinturas elaborados en nuestro continente a lo largo de los siglos XVI y XVII, puesto que la cultura escrita en comunión con las artes visuales se encargaron de crear la imagen conceptual y gráfica de los grandes gobernadores orientales.

Palabras clave: Roxolana, Hürrem, Solimán el Magnífico, imagen de poder, Nicolay, Vecellio.

AbStRact: The aim of this article is to analyse the images of power surrounding Süleyman the Magnificent and his wife, Roxolana. In order to understand the sultan's splendour the article deals with three key aspects. The first one is the palace as an architectural ensemble which reveals the governor's power. The harem was located there as well, which leads us to reflect the role of women in the Turkisch society, and especially the role of Roxolana, the Great Turk's favourite. Consequently, 
we study the chronicles, travel literature, clothing books, engravings and paintings made in the sixteenth and seventeenth century. The writings together with the artworks created the conceptual and graphic images about Roxolana and Süleyman, thereby spreading their magnificence and power.

Keywords: Roxolana, Hürrem, Süleyman the Magnificent, images of power, Nicolay, Vecellio.

\begin{abstract}
A día de hoy, el conjunto de publicaciones que analiza la curiosidad hacia el mundo turco a lo largo de los siglos XVI y XVII aumenta progresivamente. ${ }^{1}$ De hecho, los historiadores han examinado las representaciones concernientes a las guerras libradas contra ellos, comprobando el interés que estas tuvieron por mantener vivo el triunfo de Occidente y de la cristiandad sobre el enemigo oriental. En este sentido, Víctor Mínguez ha centrado una de sus líneas de investigación en reflexionar acerca de la iconografía de Lepanto, ${ }^{2}$ haciendo un especial hincapié en el papel que jugaron los Austrias como defensores de la fe católica, motivo por el cual cultivaron una iconografía en la que se les representaba junto a Dios Padre, la Virgen, la Trinidad o como portadores de los símbolos cristianos por excelencia. La batalla tuvo tal repercusión que su relevancia llegó a ambos lados del Atlántico, de modo que contamos con imágenes de la contienda incluso en los virreinatos americanos. ${ }^{3}$ Además de las escenas bélicas y como se muestra a lo largo del presente texto, la fijación hacia el adversario turco quedó patente en la difusión de su imagen a través de las crónicas de viajes, los repertorios de indumentaria o los retratos de tipos orientales, elaborados en grabados y en lienzos. Las fuentes originales como la Crónica de los Turcos de Herrera y Tordesillas, ${ }^{4}$ la Palinodia de los
\end{abstract}

1. Algunas de ellas las encontramos en: José Julio García Arranz: «Entre el miedo y la curiosidad: tendencias y variantes en la imagen europea del turco durante los siglos XV y XVI», en RosARIO CAMACHO Martínez, Eduardo Asenjo Rubio, Belén Calderón Roca: Fiestas y mecenazgo en las relaciones culturales del Mediterráneo en la Edad Moderna, Málaga, Universidad de Málaga, 2012.

Miguel Ángel Bunes IbARra: «El Imperio otomano y la intensificación de la catolicidad de la monarquía hispana.» AHIg, 16 (2007), pp. 157-167. Miguel Ángel Bunes IbARRA: «La conquista turca de Bizancio según los cronistas europeos de los siglos XVI y XVI». Erytheia, 13 (1992), pp. 89-102.

2. Víctor Mínguez: «Iconografía de Lepanto. Arte, propaganda y representación simbólica de una monarquía universal y católica.» Obradoiro de Historia Moderna, 20 (2011), pp. 255-284.

3. Víctor MíngueZ: «Lepanto en los virreinatos americanos.» en RAFAel López Guzmán, Yolanda Guasch Marí y Guadalupe Romero Sánchez (eds): América: cultura visual y relaciones artísticas. Granada, 2015, pp. 175- 182.

4. Antonio Herrera y Tordesillas: Crónica de los Turcos: la cual principalmente sigue a la que escribió Juan María Viçentino, cronista de Mahometo, Bayasit y Suleyman, 1565. 
Turcos de Díaz Tanco, ${ }^{5}$ las Repúblicas del Mundo de Jerónimo Román, ${ }^{6}$ o la Historia pontifical compuesta y ordenada por Gonzalo de Illescas, ${ }^{7}$ merecen una detenida lectura con el objetivo de percibir la capacidad militar que poseyó el imperio. Los cuatro libros son de excepcional utilidad para entender la composición de esta potencia, comprender la labor desempeñada por los visires, los consejeros o los jenízaros, así como disfrutar de relatos en relación a las batallas acaecidas en la época. La existencia de estas fuentes históricas en los siglos XVI y XVII es consecuencia de querer conocer la organización militar y el modo de proceder en la batalla del enemigo turco. Cabe destacar que sus autores son occidentales e intencionadamente, vertieron en sus descripciones múltiples descalificaciones hacia los turcos. En esa dirección se han encaminado las aportaciones de Fernández Lanza, quien ha analizado el carácter peyorativo de los textos europeos al abordar la cuestión otomana. ${ }^{8}$ Como ya se ha indicado, al revisar la bibliografía más reciente también se encuentran estudios que arrojan valiosa información sobre la intención que existió en época moderna de conocer profundamente la realidad del Gran Turco.

Si bien las fuentes escritas de la época para conocer a Solimán y sus súbditos fueron numerosas y ello permite disponer de documentos originales con cierta facilidad, no sucede lo mismo con Roxolana o Hürrem. Tan solo Vitae et icones sultanorum Turcicorum de Boissard o el escrito de Giovanni Sagredo acerca de las Memorie istoriche de monarchi ottomani vuelcan información respecto a la polémica sultana. ${ }^{9}$ El segundo de ellos es un interesante volumen para saber los tejemanejes que llevó a cabo esta dama, y la influencia que ejerció en

5. Vasco Díaz Tanco: Palidonia de los Turcos, Orense, 1547. Se ha consultado el facsímil publicado por la Diputación Provincial de Badajoz en 1947. Esta fuente es de gran interés porque estamos ante un escrito puntero, impreso en España, al tratar plenamente el conflicto turco. Es posible extraer múltiples referencias de carácter militar puesto que narra las contiendas libradas por Selim y Solimán, así como la composición de sus ejércitos. Sin embargo, es una obra limitada para comprender los rasgos culturales que definían a la potencia turca, tan solo menciona el modo de vestir y describe la vivienda del sultán o menciona las lenguas que se hablaban en la corte. Asimismo, hay pocas alusiones a la realidad general de las mujeres y en concreto de la sultana y de la influencia que debió ejercer en el ámbito político.

6. Jerónimo Román: Repúblicas del Mundo divididas en XXVII libros, Medina del Campo, 1575. Esta obra es complementaria a la de Vasco Díaz, pues tiene por finalidad enseñar las costumbres y el modo de vivir de otros pueblos. Cabe destacar que el autor fue fraile y cronista de la Orden de San Agustín, natural de la ciudad de Logroño y dedicó su libro al monarca Felipe II. Igualmente y como sucede por norma general en todos los escritos occidentales sobre los otomanos son constantes las connotaciones negativas que se vierten sobre ellos. En este sentido, se les cataloga de hombres pertenecientes a «la secta de Mahoma» la cual está gobernada por «sucias y torpes leyes».

7. Gonzalo De Illescas: Historia pontifical y católica, en la cual se contienen las vidas y hechos notables de todos los Sumos Pontífices Romanos: con más una breve recapitulación de las cosas de España, y la descendencia de los Reyes de ella, Madrid, 1613. Este libro es especialmente útil para localizar narraciones sobre los pasajes de guerra protagonizados por Solimán.

8. FERNANDO FERNÁNDEZ LANZA: «Los turcos y lo turco a través de los impresos y manuscritos hispanos del siglo Xvi. Propaganda y silencio» en Manuel Casado Arboniés (coord.): Escrituras silenciadas en la época de Cervantes, Universidad de Alcalá, 2006, pp. 75-96.

9. JEAN JACQUES BOISSARD: Vitae et icones sultanorum Turcicorum, principum Persarum aliorumq[ue] illustrium heroum heroinarumq[ue] ab Osmane usq[ue] ad Mahometem II. Francf. ad Moen, 1596.

GIovanni Sagredo: Memorie istoriche de monarchi ottomani, Venecia, 1673. 
el gobierno del Imperio. No obstante, tuvo una mayor acogida en la literatura teatral o en los libretos de ópera que en las narraciones históricas. Actualmente se dispone del volumen editado por Galina Yermolenko, un sólido trabajo referente a la presencia de Roxolana en la literatura europea. ${ }^{10}$ En cuanto a la bibliografía genérica publicada sobre este personaje, Encarna Sánchez aportó un estudio panorámico del mundo femenino en el cual se hace eco del revuelo que formaron su hija Mirhimâh y ella en las tierras occidentales. Igualmente se cuenta con aportaciones, como la de Leslie Pierce, centradas en el papel desempeñado por las esposas de los sultanes y su vida en el harén de palacio. ${ }^{11}$

Otras fuentes originales que se han analizado corresponden a la literatura de viajes e indumentaria. Estas obras son importantes porque ayudaron a difundir la imagen del turco y sus súbditos. En efecto, los autores más destacados de la época fueron Nicolás de Nicolay ${ }^{12}$ y Cesare Vecellio, ${ }^{13}$ quienes ilustraron sus obras con representaciones de tipos orientales y elaboraron un amplio repertorio visual que utilizaron los artistas contemporáneos o posteriores [Figs. 1 y 2].

El principal cometido de este estudio es valorar la imagen de poder que las crónicas, los libros que describían el vestir de otros pueblos, grabados y lienzos producidos exclusivamente en Europa vertieron por el continente sobre Solimán, Roxelana y el ejército turco en los siglos XVI y xviI. Por esta razón al artículo está vertebrado en tres cuestiones primordiales: la primera de ellas reflexiona sobre la figura de Solimán el Magnífico y su capacidad militar, confrontando los relatos históricos que describían las hazañas del sultán, la composición de su ejército y la función desempañada por cada uno de sus miembros con las representaciones halladas en las obras de Nicolay y Vecellio, ya que ilustran y ponen de manifiesto la jerarquía de la sociedad turca. El segundo componente que se analiza es el palacio, por ser la expresión arquitectónica de la magnificencia de Solimán y por ser el espacio de encuentro entre el sultán y su mujer. El harén era uno de los elementos más representativos del conjunto palatino, por ello se ha considerado nece-

10. Consúltese Galina I. Yermolenko (ed.): Roxolana in European Literature, History and Culture, Ashgate, 2010.

11. Véase Leslie P. Pierce: The Imperial Harem: Women and sovereignty in the Ottoman Empire, Nueva York, Oxford University Press, 1993.

12. NiCOLÁS DE NiCOLAY: Les quatre premiers livres des navigations et pérégrinations orientales, Lyon, 1567. El autor (1517-1583) nos ha legado una interesante y amplia crónica explicativa acerca del viaje que en 1549, junto con el embajador de Francia, hizo por el Mediterráneo con destino en Estambul. La obra al completo se divide en cuatro libros que custodian un total de sesenta figuras femeninas y masculinas tomadas del natural. Los diseños reflejan la variedad de identidades geográficas, trajes, costumbres, rituales y modos de vida de tierras lejanas.

13. Cesare Vecellio: Habiti antichi, overo raccolta di figure delineate dal Gran Tiziano, e Cesare Vecellio suo fratello, diligentemente intagliate, conforme alle Nationi del Mondo,Venecia, 1664. El autor veneciano (1521/31 - 1601) nos ha legado incontables imágenes sobre personajes turcos y orientales, además de italianos, alemanes, polacos, españoles, franceses, ingleses, húngaros, alemanes e incluso, americanos. Su libro de indumentaria se imprimió por primera vez en 1590. Al tratarse de un volumen destinado a mostrar la cultura del traje, entendida como huella etnográfica, las figuras que en él aparecen vienen acompañadas por descripciones de las piezas, los colores y los tejidos que componen el atuendo del representado. 


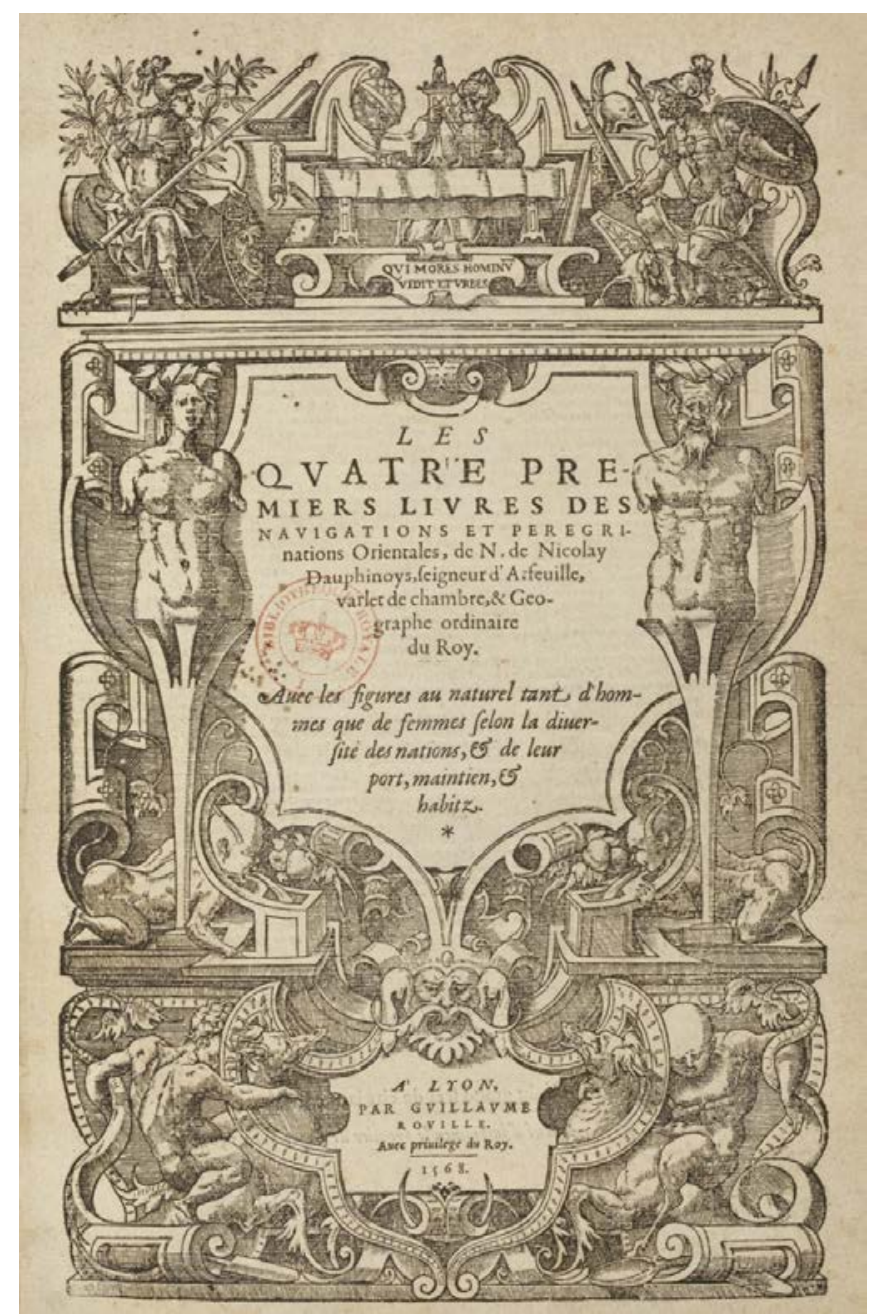

Fig. 1. NiCOLÁS DE NiCOLAY, Les quatre premiers livres des navigations et pérégrinations orientales, 1568, Lyon, Biblioteca Nacional de Francia

sario tener en cuenta la realidad femenina en el Imperio otomano. Por tanto, la aportación del estudio en este sentido se nutre de las descripciones que autores occidentales hicieron del palacio así como de la mujer turca, contextualizándola en situaciones cotidianas, potenciando su papel de madre y remarcando su sometimiento hacia el hombre, hasta el punto de no poderse dejar ver por otros varones. Nuevamente, las imágenes extraídas de Nicolay y Vecellio enseñan la apariencia de las mujeres, desde la más humilde hasta la más poderosa. El tercer y último aspecto abordado se ha centrado en la figura de Roxolana, la favorita de Solimán. Aquí se descubren las razones por las que este personaje generó tanta expectación en Occidente, así como se 


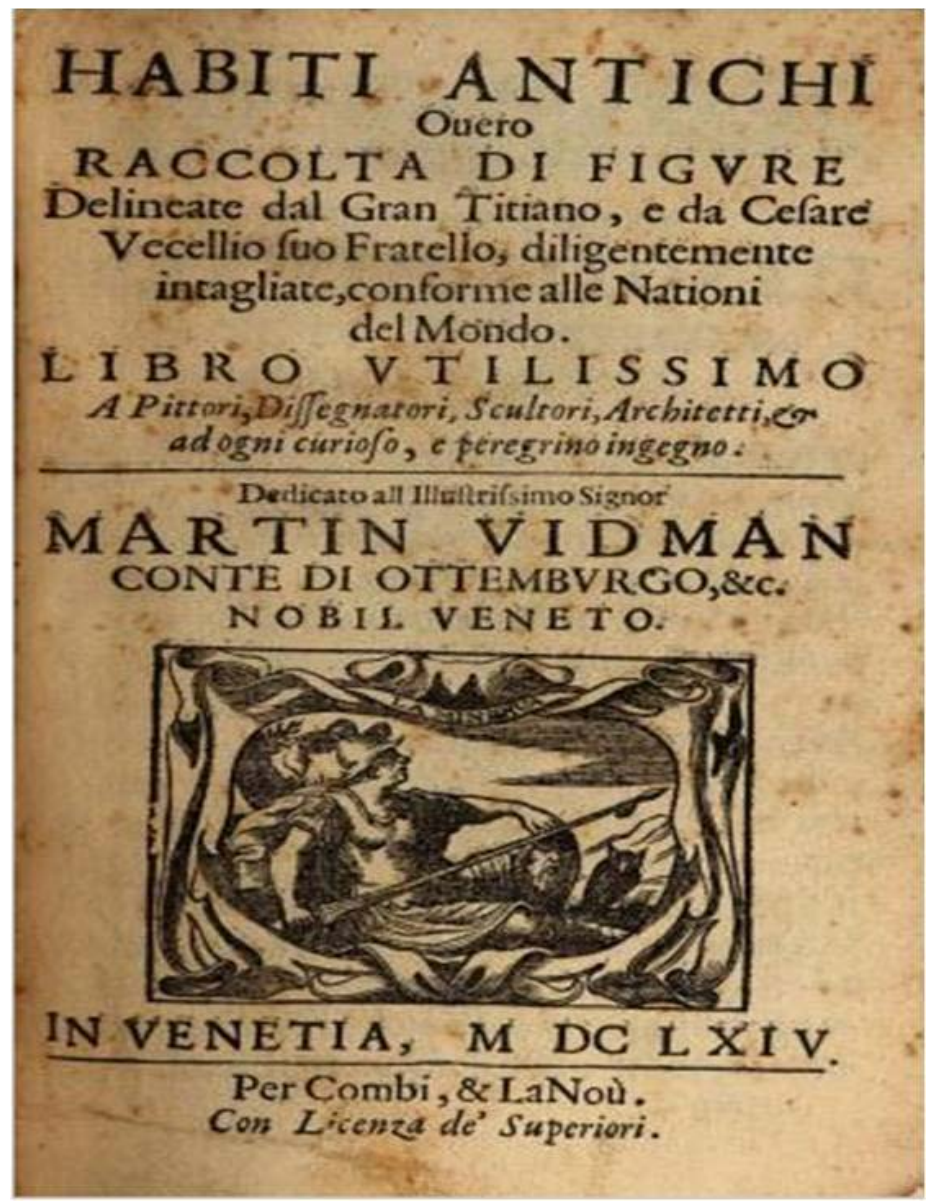

Fig. 2. CesARE VeCEllio, Habiti antichi, overo raccolta di figure delinéate dal Gran Tiziano, e Cesare Vecellio suo fratello, diligentemente intagliate, conforme alle Nationi del Mondo, 1664, Venecia

analizan los textos de la época que narraban su atractiva historia que en Europa demostraba la capacidad de influjo que tuvo la sultana sobre el Magnífico. En este apartado final también se analizan las escasas imágenes que ponen rostro a Hürrem o Roxolana. Los grabados y lienzos concuerdan con los diseños que los ilustradores de indumentaria habían elaborado para las mujeres turcas más relevantes y son prueba del interés que despertó esta dama en el imaginario europeo. En efecto, el artículo es un primer paso del largo camino que queda por recorrer, puesto que son pocos los estudios científicos que han optado por analizar críticamente las crónicas y todo tipo de fuentes literarias en unión con las artes visuales. 
Solimán el MAgNífico y SU eJÉRCito: APARIENCIA y DESCRIPCIÓN DEL PODER MILITAR

El retrato de Solimán el Magnífico atribuido a Tiziano (ca. 1530, Kunsthistoriches Museum, Viena) recoge el tipo de representación más extendido de los sultanes turcos [Fig. 3]. La efigie es un busto de perfil que concentra los rasgos físicos más característicos del emperador y que lo entroncan, indudablemente, con la estirpe otomana. Como se refiere en el primer volumen de Historia pontifical, el aspecto del sultán era descrito del mismo modo que figurado en las imágenes.

Dijeron de Solimán (que dejando aparte el no ser cristiano) en lo demás era justo, templado, continente, y liberal, y magnánimo, y ciertamente digno del Imperio que tenía. De su estatura decían, que era bien dispuesto, antes grande, que mediano de cuerpo, no muy fornido, sino antes delgado, y sacado de cuello. El rostro blanco descolorido, la nariz desosada, y muy curva, con el hueso largo, y lo demás sin barba, al modo Turquesco, y con los ojos saltados, y grandes, que le añadían ferocidad. ${ }^{14}$

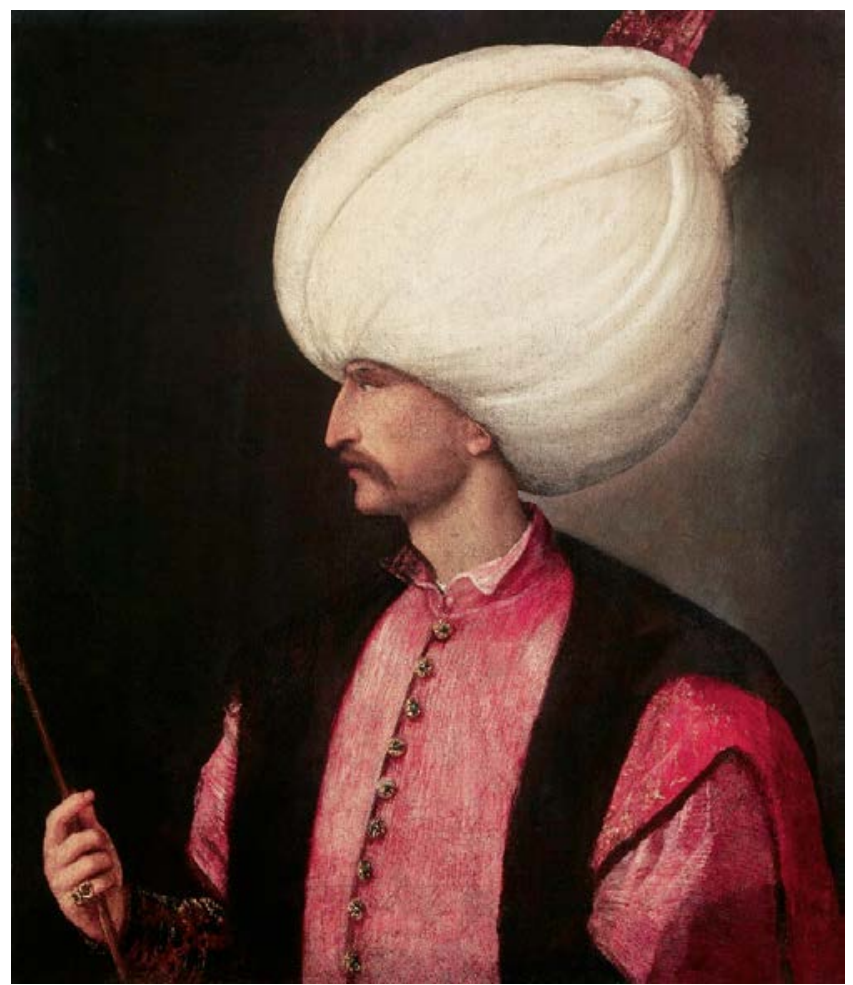

Fig. 3. Tiziano, Solimán el Magnífico, ca. 1530, óleo sobre lienzo, Viena, Kunsthistoriches Museum

14. ILLESCAS, Historia pontifical, volumen I, p. 520. 
El mandato del Magnífico (1520-1566) condujo a su pueblo hacia uno de sus momentos de mayor esplendor. No era de extrañar, pues siendo adolescente ya disponía de una cuidada formación que le permitiría obtener la sultanía en el futuro. Desde que tuvo quince años, y como sucedía con todos los príncipes herederos, aprendió de los gobernadores provinciales aquellas tareas administrativas y militares necesarias para dirigir el reino. ${ }^{15}$ En 1520, tras fallecer su padre Selim I y con veintiséis años, asumió un gobierno centrado en expandir sus dominios entre África y Europa, y alcanzó un poder tan solo equiparable al de su principal adversario, Carlos V. De hecho, las primeras actuaciones de Solimán fueron tomar la ciudad de Belgrado, someter la isla de Rodas y alcanzar el país de Hungría. También consiguió sitiar Viena, recuperó Tabriz e invadió Bagdad, y añadió Irak y el oeste de Irán a su territorio.

La clave de la fortaleza de su imperio residió en poseer una estructura compacta y de marcado carácter militar. Tras la cabeza del sultán se encontraban los bassas o visires, a quienes el Gran Turco pedía consejo en los conflictos bélicos. En tiempos de Solimán estos asesores eran «Hebrain, Ayaz y Casin, todos tres son cristianos renegados. Estos tienen extremada autoridad y son señores de infinita riqueza, mas la pompa de estos y potencia es muy peligrosa, porque siempre es combatida la envidia de muchos y según el apetito del señor muchas veces son ahorcados»». ${ }^{16}$ Como veremos, la presencia de cristianos desertores en los puestos más altos de la jerarquía del Imperio otomano no fue excepcional.

Un papel más activo en la guerra lo tenía el belerbey o señor de los señores, cargo que se podía compaginar con el de visir. En Occidente era entendido como el condestable y estaba al frente de todos los soldados a caballo. También se contaba con dos belerbeyes, caballeros de la Anatolia y Romania respectivamente. Jerónimo Román denominaba a este tipo de personaje belerbey de Europa porque disponía de gran ayuda para desempeñar los combates a cambio de una jugosa suma de dinero, cien mil ducados en gajes. En el ejercicio de la guerra, colocaban en la tienda una cola de caballo colgada de una larga lanza a modo de distintivo. Durante la batalla, portaban banderas de diversos colores para ser identificados. Asimismo dirigían a los sanjacos o alféreces, es decir, a los gobernadores de las provincias. Su número incrementó drásticamente bajo el reinado de Selim I, padre de Solimán, y además tenían la capacidad de reclutar muchísimos hombres para la contienda. En su libro, Cesare Vecellio aporta una interesante imagen del belerbey como un hombre de armas del cual subraya que lleva una lanza con hilos de colores para ser reconocido. Asimismo, la ilustración de la página contigua corresponde concretamente al caballero de la Anatolia, de quien incide en la gran estima que se le profesa [Fig. 4].

15. Para conocer más detalles acerca de la realidad que vivió el sultán se debe consultar EsıN ATIL: The age of sultan Süleyman the Magnificent, National Gallery of Art, Washington, 1987.

16. Resulta especialmente interesante tener en cuenta el conocimiento proporcionado por DíAz TANCo, Palinodia, fol. 57r. 

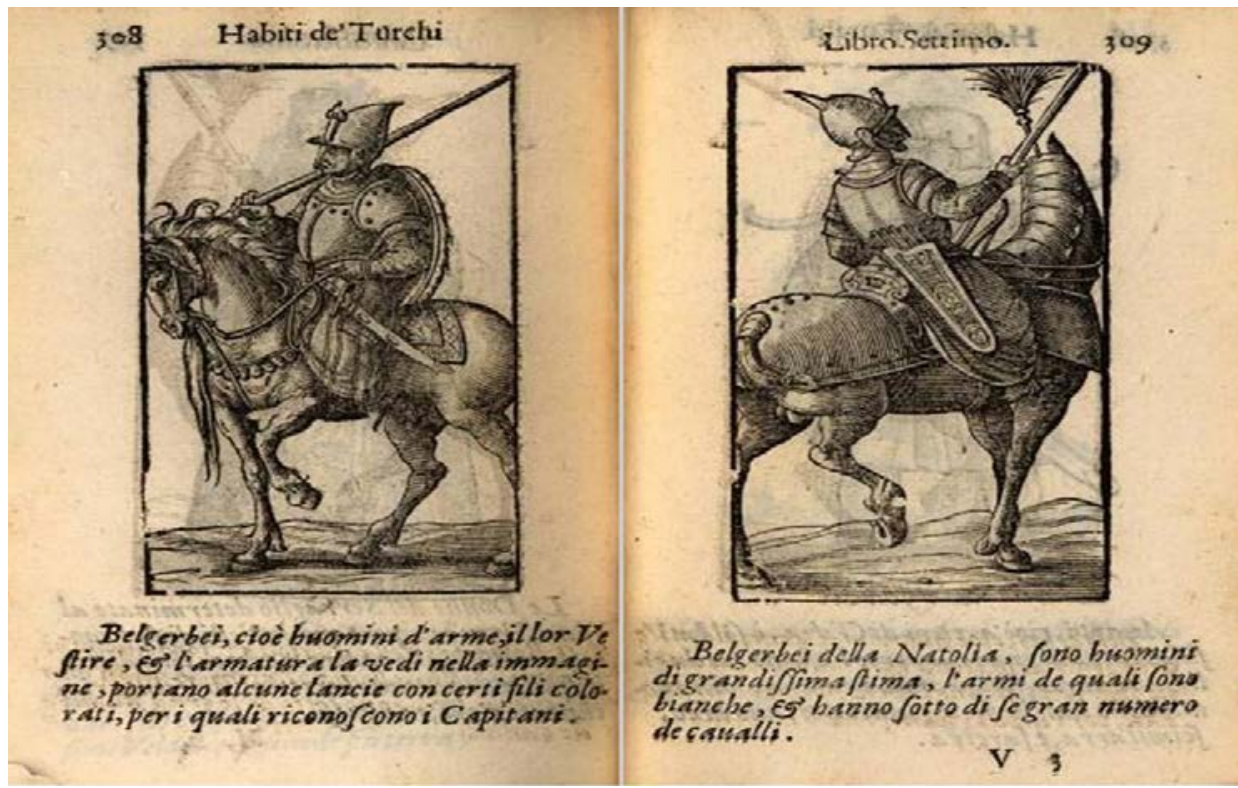

Fig. 4. Grabado del belerbey en Cesare Vecellio, Habiti antichi, Venecia, 1664

Las dos órdenes de jinetes que destacaron fueron los ulufagos y los caripices. ${ }^{17}$ Respecto a los primeros sumaban un total de mil servidores que podían haber sido fieles esclavos de los bassas o de los belerbeyes, así como proceder de la compañía jenízara. Con el tiempo conseguían honores y eran destinados al escuadrón de soldados a caballo. Cabe mencionar que se les presenta como hijos de cristianos y cristianos renegados, puesto que en su niñez se convirtieron en turcos. En cambio, los caripices:

son naturales mahometanos de todas las provincias de Levante, y son una cierta mezcla de persianos y turcos y moros, de Siria: de Berbería: de Thartaria: y de Arabia: y de otras partes diversas de la India. Tienen buen sueldo y son privilegiados de poder andar donde les parece cuando el Gran Turco está de asiento en Constantinopla, y estos cada tres lunes envían o van a la puerta a recibir el sueldo, donde luego son pagados, y así cuando el Gran Turco camina va en medio de los otros a caballo. ${ }^{18}$

A raíz de esta descripción debemos imaginar que el sultán debía ir acompañado de un sinnúmero de jinetes que lo protegían en sus desplazamientos. Una situación similar ha sido representada en el grabado de Solimán

17. Ibidem, fol. $54 \mathrm{v}$

18. Idem. Se puede ampliar los datos respecto a esto en el cap. Lxxv, Que trata de los Ulufagos y de los Caripices, $y$ de su arte y manera de vivir. 
el Magnífico y su comitiva desfilando en Constantinopla ejecutado por Pieter Coecke van Aelst (1553, Metropolitan Museum, Nueva York). La pieza forma parte de un conjunto de viñetas que vienen a mostrar las costumbres de los turcos y en ella distinguimos al sultán cabalgando a la altura de un obelisco y una considerable parte de la escolta que le precede y le sigue trotando sobre estilizados rocines.

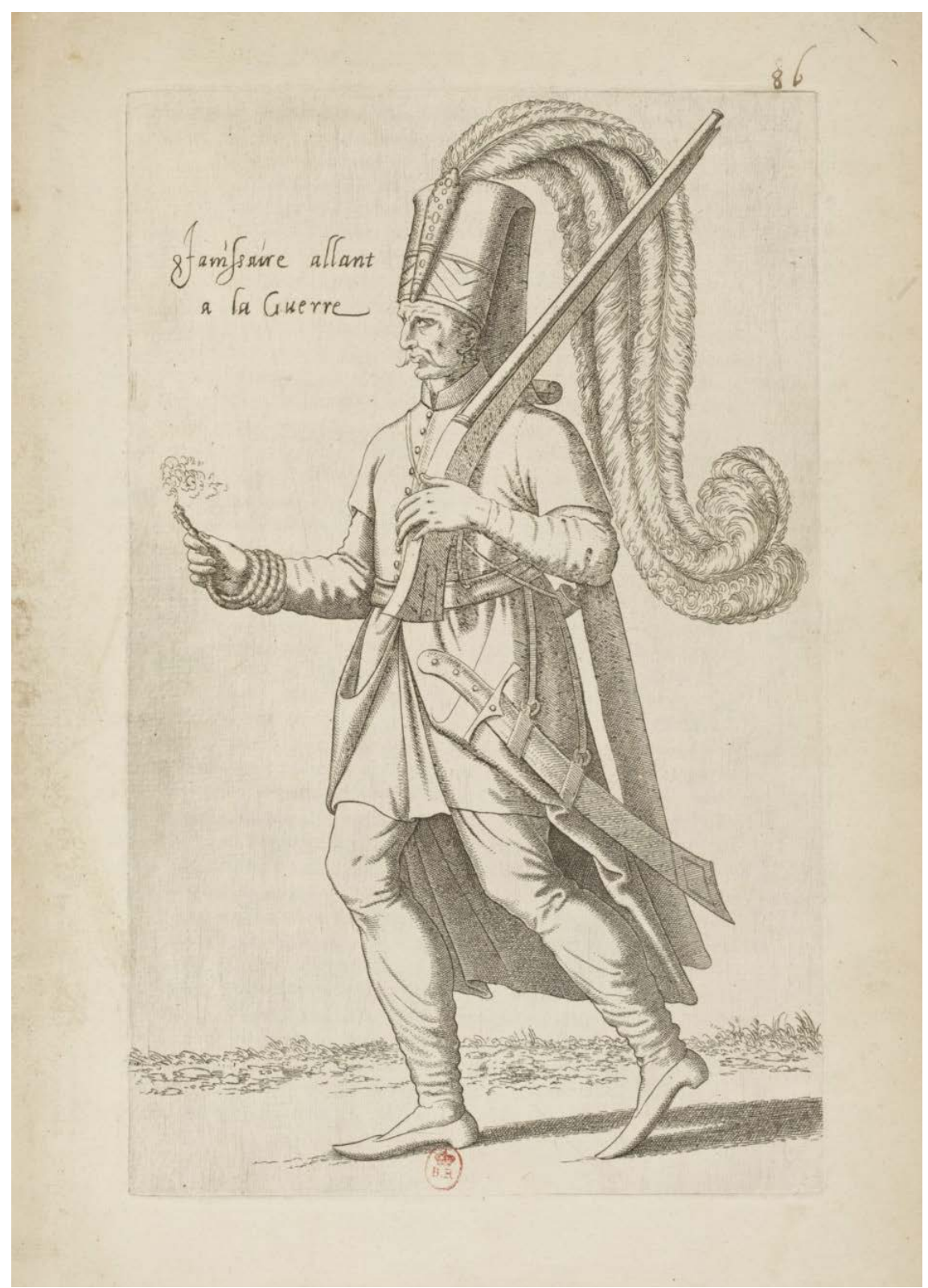

Fig. 5. Grabado del jenízaro yendo a la guerra en NiCOLÁs DE NiCOLAY, Les quatre premiers livres des navigations et pérégrinations orientales, 1568, Lyon, Biblioteca Nacional de Francia 
Otra importante fuente de suministro humano para el ejército eran los miles de jenízaros que lo componían. ${ }^{19}$ Eran infantes, originariamente cristianos, que fueron educados por los turcos en el arte de la guerra, especializándose en

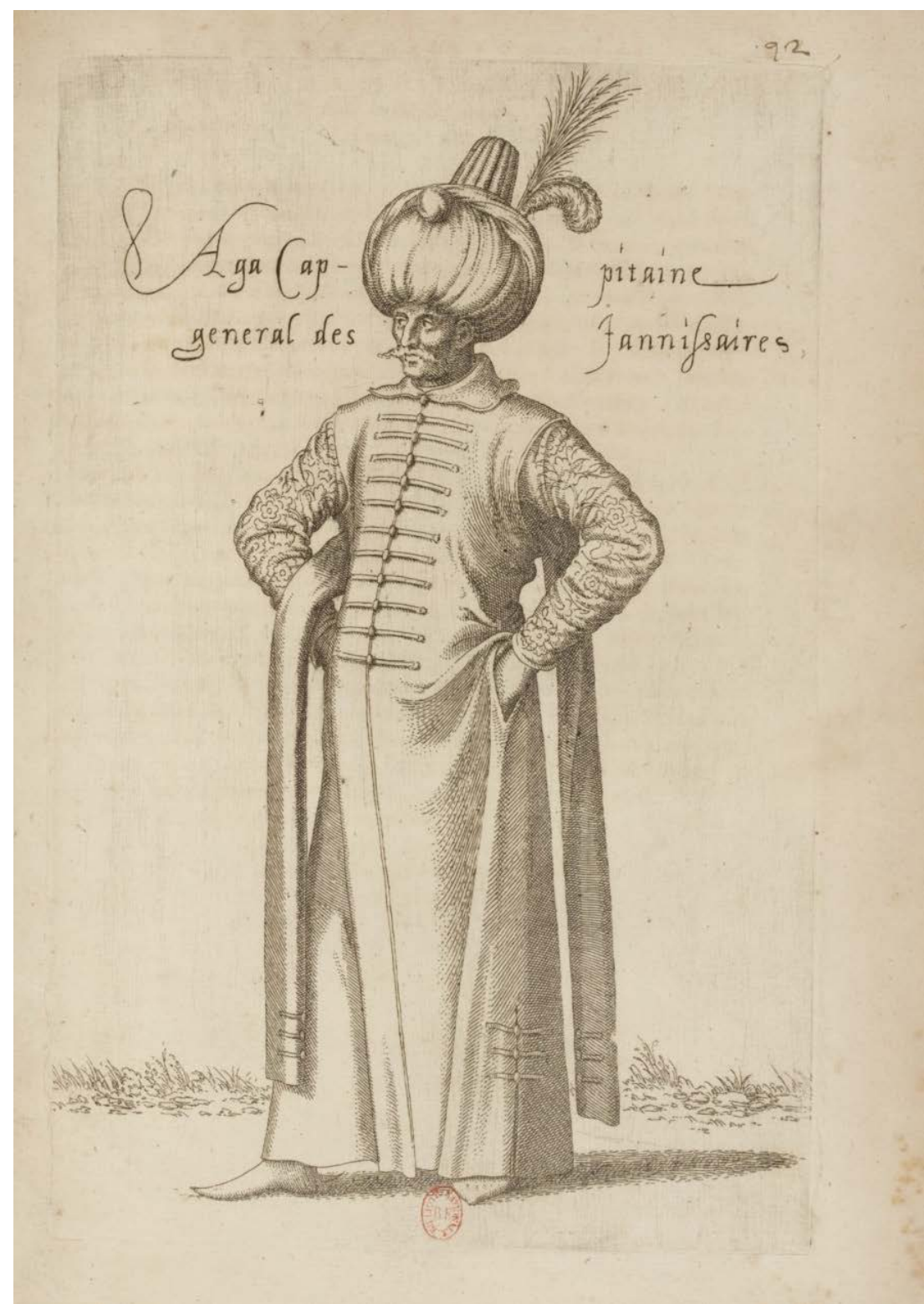

Fig. 6. Grabado del agah en NiCOLÁs DE Nicolay, Les quatre premiers livres des navigations et pérégrinations orientales, 1568, Lyon, Biblioteca Nacional de Francia

19. Ibidem, fol. 55-56r. Aquí disponemos de información más detallada sobre los jenízaros. Además de sus funciones, se explican otros aspectos como cuál era su salario o se describe la estética de su uniforme, entre otras cosas. También obtenemos datos similares en la aportación de Jerónimo Román ya referenciada. 
el empleo de arcos, escopetas u otras armas manuales [Fig. 5]. De entre todos ellos, diez mil se localizaban en los lindes de los reinos cristianos del oeste, conducidos por el agah. Nicolás de Nicolay presenta la figura de este esbelto capitán, colocando los brazos en jarra y exhibiendo la refinada calidad textil de su túnica y sobre bata. Igualmente un espectacular turbante acompañado de unas plumas confiere al personaje un aire exótico ante las miradas occidentales [Fig. 6]. Los jenízaros también albergaban un grupo de doscientos arqueros conocidos como solaquis para proteger al Gran Turco marchando a pie o a caballo. Esta compañía se ha equiparado a:

la falange macedónica con que Alejandro Magno conquistó todo el Levante, y así parece que quieren imitar a los antiguos reyes de Macedonia, aunque hay gran diferencia porque los reyes antiguos de Macedonia eran nobles y virtuosos de nación: y los turcos son viles y crueles de condición. Los otros mansos y liberales: y estos soberbios y tiranos. Los otros inclinados a virtud: y estos fundados en vicios. ${ }^{20}$

Las imágenes referentes a los solaquis son bastante comunes, de modo que Nicolay y Vecellio adjuntan diseños de estos arqueros, quienes rodeaban directamente al sultán [Fig. 7]. Por ello es común encontrarlos representados en las piezas que muestran el boato del Gran Turco. Así sucede en el caso del grabado anteriormente comentado, en la obra de Antonio Tempesta que muestra el Cortejo de Solimán el Magnífico (s. XviI, Biblioteca Nacional, Madrid) ${ }^{21} \mathrm{o}$ en galerías de retratos orientales. ${ }^{22}$

20. Ibidem, fols. $55 \mathrm{v}-56 \mathrm{r}$

21. El grabado de Tempesta fue analizado en un trabajo previo teniendo en cuenta su relación visual con los modelos de Vecellio, bajo el objetivo de comprobar que los libros de indumentaria servían de catálogo y fuente de inspiración para otros artistas que representaban escenas turcas: Cristina Igual Castelló: «Turcos en las crónicas de viajes, libros de indumentaria y retratos: cuando la imagen y la palabra dibujan una cultura.», en Encrucijada de la Palabra e Imagen Simbólicas, Palma de Mallorca, Universitat de les Illes Balears, en prensa. También encontramos una reflexión de la obra en Los Austrias. Grabados de la Biblioteca Nacional, Madrid, Biblioteca Nacional, 1993. La ficha del grabado pone de relevancia que la cabalgata de un emperador oriental se represente utilizando un lenguaje discursivo similar al que se emplearía en un desfile occidental, bajo la intención de mostrar que el enemigo turco ostentaba un poder equiparable al de Carlos V. Esta solución fue realmente lógica tratándose de un autor veneciano que conocía cómo se celebraban las entradas triunfales además de los grabados que de ellas quedaban, y que por tanto optó por fusionar el tipo de procesión occidental con los figurines de personajes orientales de Vecellio para crear una imagen entendida en Europa que concentrase la capacidad y la fuerza del Imperio otomano.

22. Se debe hacer referencia al caso de la serie pictórica de tipo orientales conservada en el Real Colegio Seminario del Corpus Christi de Valencia. Los lienzos se han basado íntegramente en las imágenes halladas en las obras de Nicolay y Vecellio. Lo exótico de la galería, el haber sido adquirida por el propio patriarca san Juan de Ribera, y el estar emplazada en una arquitectura católica durante la Contrarreforma, hacen de este grupo una atractiva empresa del que no se había hecho un nuevo análisis hasta la actualidad. Los retratos se estudian pormenorizadamente en Cristina Igual Castelló e Inmaculada Rodríguez Moya: «Sultanes, guerreros y mercaderes: Tipos orientales en el Real Colegio Seminario del Corpus Christi de Valencia», Palma Martínez-Burgos (ed.): El Greco en su IV Centenario: Patrimonio Hispánico y Diálogo Intercultural, Toledo, Universidad de Castilla-La Mancha, 2016, pp. 487-505. También es interesante el artículo de Fernando Benito Doménech: «Una enigmática serie de pinturas de turcos en Valencia», Boletín de la Sociedad Castellonense de Cultura, 57, 1981, pp. 285-294. 


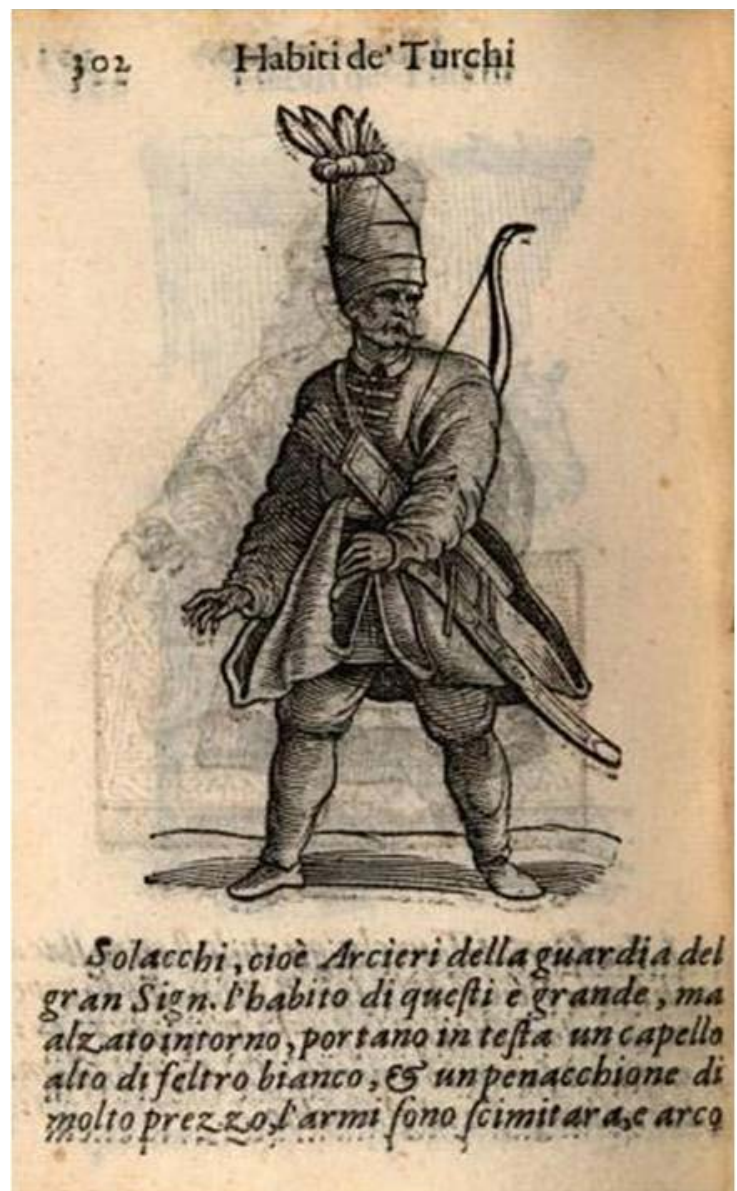

Fig. 7. Grabado del solaqui en Cesare Vecellio, Habiti antichi, 1664, Venecia

Por lo general, las crónicas asocian a los otomanos con todos los valores negativos para el pensamiento occidental, por ello se les tilda de ladrones, embusteros, agresivos y lujuriosos. Se puede interpretar que, para los escritores europeos, los defectos de los otomanos son consecuencia de seguir el islam. También hacen un especial hincapié en que muchos de los siervos del sultán poseen un pasado cristiano. Sin duda, es un aspecto llamativo en el cual subyace, una vez más, el conflicto religioso a la vez que avisa a Occidente de la capacidad que tiene el enemigo turco para convertir cristianos y nutrir su propio ejército. 


\section{EL LUjOSO SERRALLO, DONDE EL SULTÁN ENCUENTRA SU HARÉN}

El palacio simbolizaba la magnificencia y poderío del Gran Turco. ${ }^{23}$ En 1459, el sultán Mehmed II ya fundó un primer edificio en Estambul en base al construido por el emperador Constantino, que posteriormente sería conocido como palacio Topkapi. Según Nicolay estaba emplazado al otro lado de la ciudad, a la derecha de la embocadura del puerto, fortificado por altas murallas y en medio se apreciaba un bello y delicioso jardín, que nacía desde la colina y descendía hasta el mar. Era el lugar de residencia del Gran Señor de Turquía cuando este se encontraba en Constantinopla. En el conjunto fortificado había múltiples viviendas sostenidas por columnas, que recordaban los claustros occidentales. También se distinguían doscientas habitaciones aproximadamente, de las cuales la mayor parte estaban reservadas para el sultán por ser el lugar más elevado, fresco y abundante de buenas aguas. ${ }^{24}$ Las descripciones de los distintos autores coinciden en alabar la belleza y lo idílico de su entorno.

Tiene diversas arboledas y jardines y los aposentos son muy grandes y labrados con maravilloso artificio, [...] están labradas las paredes de labores ricas y adornadas de mucho oro y de trecho en trecho hay como mazonerías y claraboyas labradas de plata y sembradas en ellas piedras de gran precio. ${ }^{25}$

El Serrallo, por su posición, por su hermosura, por el fantástico panorama que en torno suyo se desarrolla, parece la mansión del encanto, el templo de todos los placeres. Hermosos edificios, bellísimos jardines, sombra, frescura, poesía, el Bósforo que se desliza majestuoso como un inmenso río, reflejando en sus ondas este conjunto de belleza... tal es el aspecto del Serrallo. ${ }^{26}$

La riqueza y el lujo impregnaban la construcción al completo, especialmente la estancia destinada a recibir a los embajadores y las dependencias del propio sultán. Igualmente los textos explican al detalle que el menaje, el ropaje de los dormitorios o el vestuario del emperador o el modo de servirlo eran exquisitos.

23. El palacio o serrallo denomina, además del conjunto palatino, el harén del sultán. En este sentido, Encarna Sánchez aporta una minuciosa explicación acerca del porqué emplear la misma palabra para designar ambos espacios. Así pues, afirma que el término serrallo procede, en origen, del vocablo turco y persa serai, entendido como espacio de residencia, alojamiento o palacio. No obstante, la lengua italiana adaptó la palabra serai como serraglio que también remitía a la jaula donde se encerraban las fieras. Dicha transformación fue realmente eficaz porque aludía al palacio, pero también al lugar donde las mujeres turcas vivían sin tener contacto con el exterior, es decir, el harén. Véase ENCARNA SÁNCHEz GARCíA: «El mundo femenino turco en la literatura castellana del siglo XVI.» en José ANTONio GonzÁLEz AlCANTUD y ANDRÉ STOLl (coord.): El Mediterráneo plural en la Edad Moderna: sujeto histórico y diversidad cultural, Anthropos, 2011, pp. 132-167.

24. NiCOLAY, Les quatre premiers, pp. 65-66.

25. Román, Repúblicas, fol. 436.

26. Vicente Moreno de la Tejera: Diario de un viaje a Oriente, Argel, Nápoles, Pompeya, el Vesubio, Sicilia, Grecia, el Archipiélago, Turquía y Egipto, Madrid, ca. 1877, edición Madrid, p. 171. 
Los aposentos a donde el Gran Turco vive todos están cubiertos por el suelo de alfombras de hilo de oro, plata y seda y todas las piezas secretas a donde no entran más que los privados están de esta misma manera aderezadas, pero no usan de camas altas ni de sillas como las nuestras más todo está en el suelo o las sillas son bajísimas. Cuando el gran Turco está retraído tiene por silla un estrado con dos colchones pequeños de tela de plata y oro con ricas borlas, y cuatro almohadas o cojines de diversos colores y sedas. [...] De invierno el Turco duerme entre sábanas aforradas en ciertas pieles de animales finísimos y preciosos que cuestan mucho. En verano las sábanas son delicadísima holanda o de tafetán, y no sirven más que una noche al Gran Señor, y son de los camareros que son quince mancebos de los más gentiles hombres jenízaros que hay en casa del Turco y no son de más edad que de diez y seis años hasta veinte y andan vestidos de brocado o de otras finísimas sedas. Cuando ven los camareros que es hora que el Gran Turco se acueste le hacen la cama en el suelo sobre alfombras ricas y hecha la cama le ponen un cobertor de tela de oro o de otra cosa preciosa y a los cuatro cantones de la cama encienden cuatro gruesas velas de cera blanca y las ponen en unos candeleros bajos y van al aposento a donde como dicen la hora que es, y él va a su aposento desnudo en camisa, quitan aquel cobertor que no es más de para majestad, y al lado que se vuelve matan las dos velas y quedan las otras encendidas, y todas las veces que se menea la encienden las velas que caen a las espaldas, y apagan las que le daban en los ojos. Para esto velan cinco camareros toda la noche por sus horas y tiempos, los que lo velan están de rodillas al cantón de la cama, esto se hace así cuando duerme solo, que cuando está con su mujer no se puede saber fácilmente que orden se tiene. ${ }^{27}$

El diseño arquitectónico del palacio se vertebraba, principalmente, en torno a tres patios en los que tenían lugar actividades administrativas del reino y se les proporcionaba educación a los miembros de la corte. El primero de ellos era el denominado birún, un espacio público donde se ubicaba la casa de la moneda, la guardia, el personal de mantenimiento, los proveedores, los jardineros, los arquitectos, artesanos y artistas que estaban al servicio del sultán. Al segundo patio solo se accedía en la celebración de actos oficiales. Aquí se encontraban las dependencias del gran visir, así como las cocinas y establos imperiales. De hecho, la descripción de Nicolay matiza que en la caballeriza se mantenía diariamente a cuarenta o cincuenta de los más bellos corceles. ${ }^{28} \mathrm{El}$ tercer patio era un lugar completamente privado donde se localizaba el santuario, el personal de la escuela llamada enderun, que se encargaba de instruir a los muchachos jenízaros y a los niños o niñas que aprendían a servir en palacio. Respecto a ello, estos eran criados desde los ocho hasta los veinte años, tiempo en el cual eran educados en la religión y en las actividades militares, como

27. A continuación, el texto también hace referencia al fasto que se mantenía en la cultura de la mesa. El sultán era servido por un eunuco que trabajaba como maestro de sala. Los manjares le llegaban en una vajilla de porcelana y la bebida se le proporcionaba en un vaso de madera preciosa, huyendo de los recipientes de oro o de plata, con la finalidad de evitar tomar agua o cerveza envenenada. Román, Repúblicas, fol. 436-437.

28. NiCOLAY, Les quatre premiers, p. 66. 
cabalgar a caballo o tirar con arco. ${ }^{29}$ Igualmente allí se situaba el harén, término que significa literalmente lugar sagrado o vedado, ello pone de manifiesto su relevancia como espacio dedicado exclusivamente a la vida de las mujeres y sus hijos. En origen, se localizaba en el antiguo palacio emplazado en el centro de la ciudad. Antes del año 1550, señoras e infantes tenían vetado el acceso al palacio Topkapi hasta que se les permitió trasladarse allí.

En este mismo Serrallo y gran palacio está el de la Gran Turca, o Emperatriz y es casi tan grande como el del Gran Turco, y tiene sus pasadizos por donde el Turco pasa a donde ella está muy secretos, y no puede entrar hombre alguno a los aposentos de la Gran Señora, sino es un eunuco, que es como su mayordomo, del cual fía todos los negocios de mucha importancia, y por tener oficio tan preeminente anda vestido con ornamentos representadores del cargo que tiene. Dentro de su palacio tiene mezquitas, baños y jardines, así para su persona, como para sus damas, las cuales son ciento, y está a su cargo casarlas con los jenízaros que suben a oficios honrosos en casa del Gran Turco. Nunca sale la gran Turca fuera de casa, ni se deja ver de nadie, salvo de los que la sirven, y si alguna vez sale es metiéndose en una litera muy cerrada, en todo lo demás es servida con la majestad que el gran Turco. ${ }^{30}$

La descripción de Jerónimo Román, acerca de la imposibilidad de ver la apariencia física de la sultana, se encuentra perfectamente ilustrada en la pieza de Cesare Vecellio. Concretamente en su séptimo libro, donde aborda la indumentaria turca, disponemos de una imagen sobre cómo salía la emperatriz por la ciudad. Se desplazaba a caballo y cubierta completamente por un baldaquino rectangular sostenido por cuatro asistentes [Fig. 8].

Nicolay matizó que más de doscientas mujeres y concubinas del Gran Turco habitaban allí, teniendo a su disposición numerosas viviendas, con cocinas y otros servicios. La mayor parte de ellas eran hijas de cristianos capturadas en las empresas bélicas contra los griegos, húngaros, valacos, italianos y otros pueblos. También podían ser compradas a comerciantes y seguidamente presentadas por los belerbeyes, bassas y capitanes al sultán, quien las acogía en su morada, las alimentaba, las vestía y las entretenía bajo la firme vigilancia de los eunucos, es decir, de hombres castrados exclusivamente encargados de protegerlas. Cada diez de ellas, estaban sujetas a la directa supervisión de una matrona que las educaba y les enseñaba labores de costura. ${ }^{31}$

Las mujeres del harén se podían clasificar jerárquicamente según su rango, así pues la madre del sultán era la más importante y tenía la potestad de aconsejar a su hijo en cualquier asunto, tanto del día a día de palacio como en contenidos de política nacional e internacional. Tras ella se encontraba la favorita o la haseki, para quien su principal cometido era ofrecer hijos varones

29. Ibidem, p. 66

30. Román, Repúblicas, fol. 436.

31. Nicolay, Les quatre premiers, p. 67. 


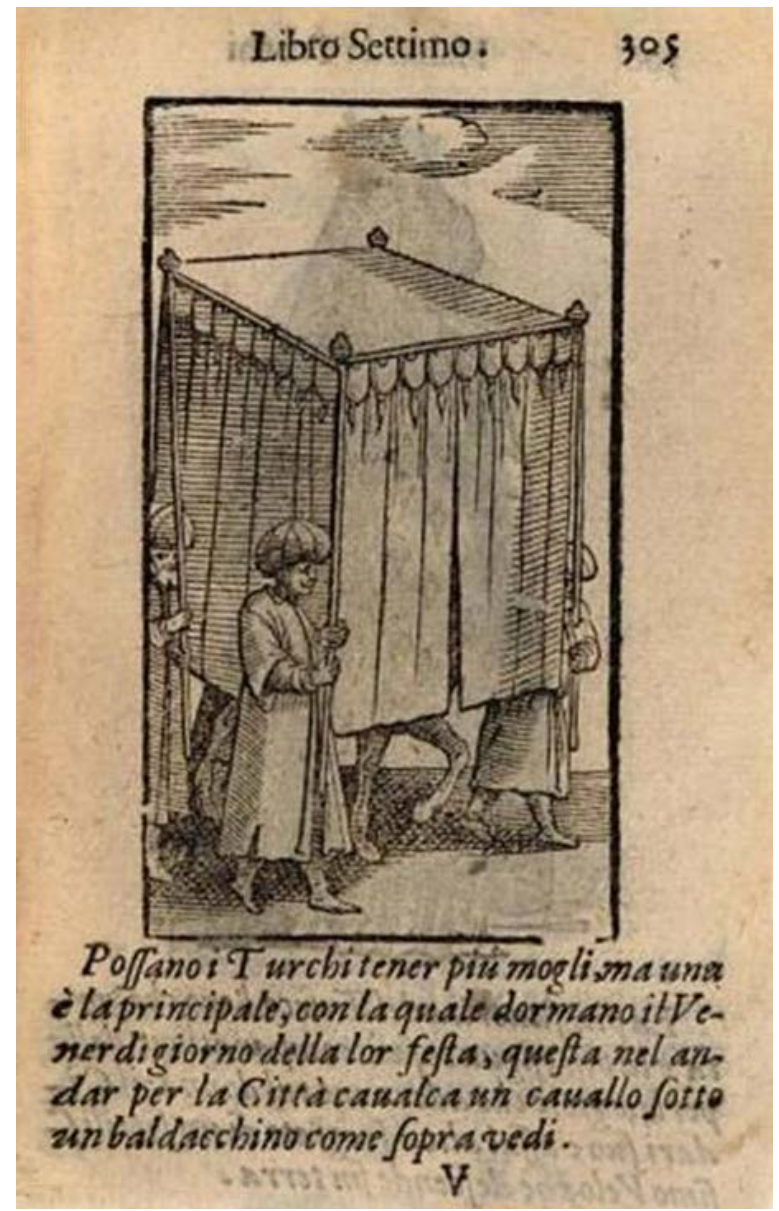

Fig. 8. Grabado de la esposa turca a caballo cubierta por un baldaquino, en Cesare Vecellio, Habiti antichi, 1664, Venecia

al Gran Turco y finalmente, quedaban el resto de princesas o şhezades. ${ }^{32}$ Como se ha observado y a excepción de las mujeres más próximas al sultán, que podían influir en las cuestiones políticas, el resto de damas quedaban circunscritas a los espacios privados. En efecto, las crónicas contextualizan a las mujeres en el cuidado de los hijos, en algunos paseos por la ciudad o en visitas a los baños [Fig. 9]. La asistencia al baño era una costumbre arraigada en la sociedad turca, practicada tanto por las señoras de mínima categoría social como por las damas ilustres con la finalidad de cuidar su salud y su belleza. No obstante, las humildes asistían a los baños públicos, mientras que

32. Respecto al diseño arquitectónico del palacio, las funciones que desempeñaba cada uno de sus espacios y al harén se puede encontrar más información en ATIL, The age of sultan, pp. 20-21. 
las afortunadas disponían de ellos en sus propios hogares o en el serrallo. A menudo iban en grupos de diez o doce, incluso alguna más, y se lavaban con familiaridad unas a otras. ${ }^{33}$

$\mathrm{Al}$ trabajar con fuentes escritas originales producidas en Occidente, se ha podido comprobar que los autores europeos han centrado sus descripciones sobre el Imperio otomano en mostrar la rígida estructura militar que respaldaba al sultán. Sin embargo, los relatos concernientes a las costumbres o al papel de la mujer en este tipo de sociedad son realmente escuetos. En comparación con las alusiones a los varones, la atención vertida a la realidad de las mujeres es prácticamente nula, tan solo se las menciona en contextos domésticos y privados. La invisibilidad de la dama turca hacia la sociedad estaba muy arraigada en sus tierras, sin embargo los textos y las imágenes europeas también contribuyeron a mantenerlas escondidas [Fig. 10].

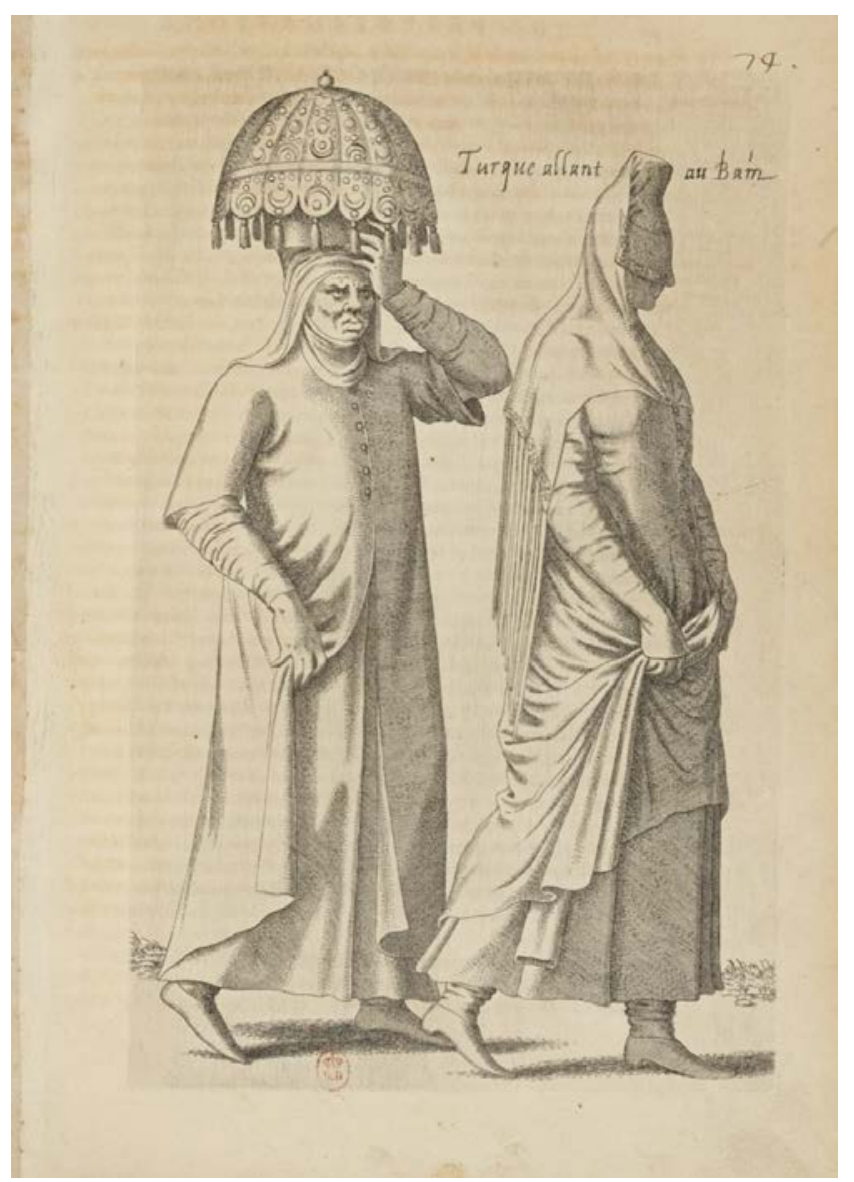

Fig. 9. Grabado de las mujeres hacia el baño en NiCOLÁs DE NiCOlaY, Les quatre premiers livres des navigations et pérégrinations orientales, 1568, Lyon, Biblioteca Nacional de Francia

33. NicOLAY, Les quatre premiers, pp. 72-73. 


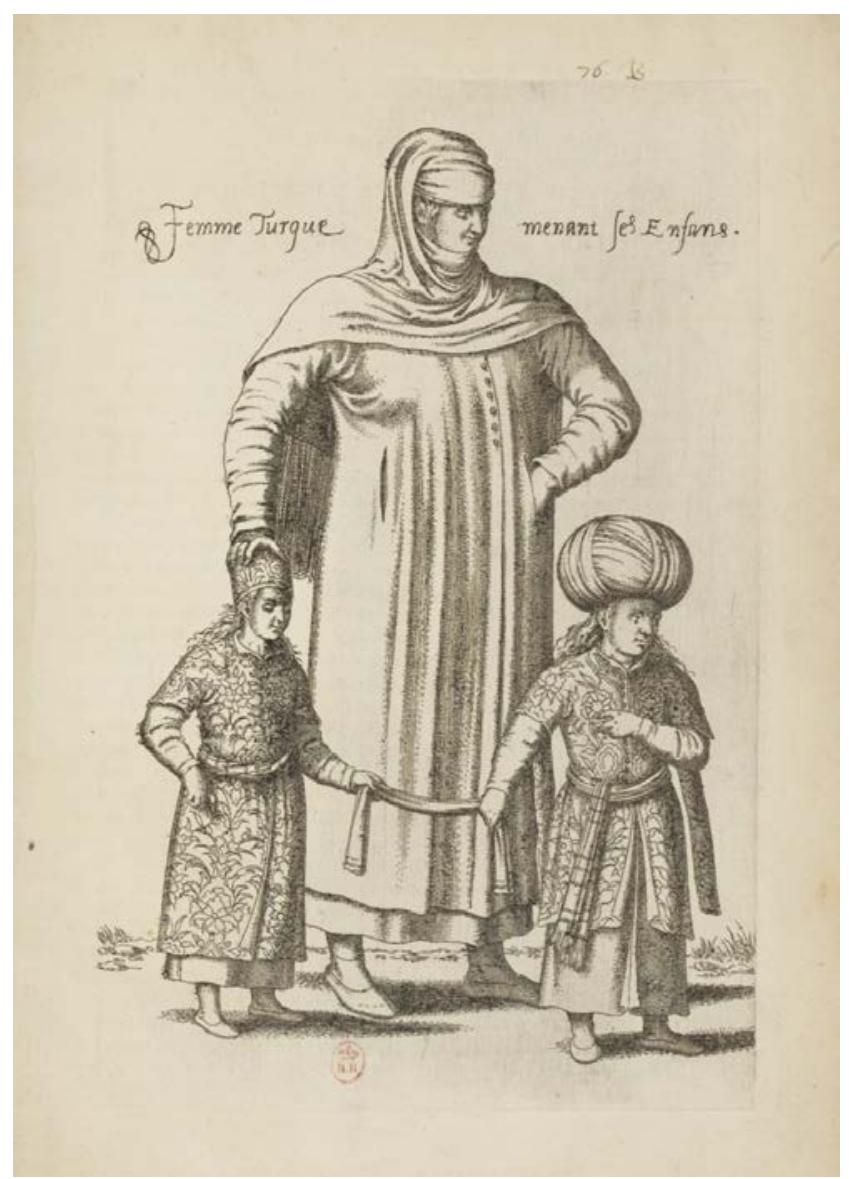

Fig. 10. Grabado de la mujer turca al cuidado de los niños en NiCOLÁs DE NiCOLAY, Les quatre premiers livres des navigations et pérégrinations orientales, 1568, Lyon, Biblioteca Nacional de Francia

\section{ROXOLANA, LA ELEGIDA POR SOLIMÁN, EN LA CÚSPIDE DEL PODER FEMENINO}

Roxolana (1500-1558), llamada Hürrem en Oriente, fue la favorita del Gran Turco Solimán el Magnífico. Quizás debido a su origen europeo, posiblemente el haber sido la predilecta del sultán más poderoso, tal vez la influencia que se le atribuye en cuestiones políticas, o incluso el rumor de ser la orquestadora de la muerte del primer heredero, consiguieron que Hürrem captase poderosamente la atención de Occidente a lo largo de la Edad Moderna. Su belleza y personalidad eran temas de obligado tratamiento en los círculos diplomáticos y reuniones de la alta sociedad del momento. Así pues, corrieron ríos de tinta para mostrar el esplendor de los sultanes otomanos y avisar del serio peligro que podían suponer para la espiritualidad occidental. 
Las reflexiones de Encarna Sánchez alrededor de la mujer turca en la literatura castellana del siglo Xvi son un buen punto de partida para conocer en profundidad al segundo amor de Solimán. ${ }^{34}$ El nombre de este personaje varía de Oriente a Occidente, pues para el mundo turco fue Hürrem, que se podría traducir por «alegre»o «sonriente». ${ }^{35}$ En cambio, en Europa fue conocida como Roxolana, Roxelana, Roxana o la Rossa, haciendo referencia al color rojizo de sus cabellos. En relación a la procedencia de la sultana, la misma autora respalda la idea de que era una mujer de raíces polacas aunque nacida en la región rusa de Rutenia. Hija de un sacerdote ortodoxo, probablemente se convirtió durante su niñez en prisionera del dominio turco. Cuando Solimán alcanzó el trono en 1520 la joven fue llevada ante él y comenzó a formar parte de su harén. Su poder de atracción fue en aumento hasta que obtuvo el título de haseki, apelativo que la presentaba como la favorita del sultán. El nacimiento de su primer hijo en 1521 no hizo más que afianzar su poder hasta que, dos hechos decisivos en 1534 la consolidaron como una figura femenina de inmensa autoridad. Por un lado y sorprendentemente, el sultán decidió celebrar un matrimonio legal con esta querida, un acontecimiento extraordinario desde el siglo xv. Y por otro lado, el fallecimiento de la madre de Solimán, la mujer más relevante en el harén, hizo que Roxolana ascendiese a la cima de la pirámide social.

Resulta verdaderamente interesante consultar las Memorie istoriche de monarchi ottomani de Giovanni Sagredo para disponer de más información sobre la sultana e imaginar la percepción que se tenía acerca de ella y que llegó hasta el siglo XVII. Entre las primeras referencias hechas por el autor encontramos, concretamente en el libro séptimo dedicado a Selim II (hijo del Magnífico), una comparación entre los dos principales amores de Solimán. La Circassa fue su primera concubina y había engendrado cuatro hijos: Mustafá, Giango, Meemet y Baiazet. Aunque se llamaba Mahidevran, seguramente el escritor italiano la denominó así por sus ascendientes circasianos. Se la define como una mujer arrogante, cruel, mordaz y severa. Por el contrario, Roxolana era la madre de Selim II, quien se convertiría en heredero del imperio. Según Sagredo se la tilda de astuta, artificiosa y política: «Hebbe Solimano suo Padre due mogli, la Circassa, e Rosolana, detta la Rossa. La prima era dona superba, aspra, severa; la seconda esclatra, artificiosa, politica. La Circassa era Madre di Mustafà, Giangor, Meemet, e Baiazet; la Rossa di Selino, tutti figli

34. SÁNCHEZ, El mundo femenino turco, pp. 132-167.

35. Respecto a los orígenes de Roxolana y sus principales rasgos biográficos, se puede consultar la aportación de Leslie P. Pierce: The Imperial Harem: Women and sovereignty in the Ottoman Empire, Nueva York, Oxford University Press, 1993. La autora, al igual que sucede en otros referentes bibliográficos, matiza que la favorita del sultán podía despertar el odio entre sus contemporáneos porque se la presentaba como una mujer egoísta, manipuladora y estratega para que uno de sus descendientes accediese al trono tras el fallecimiento de Solimán. Asimismo, disponemos de un estudio que analiza el impacto cultural de este personaje en Oriente y Occidente con Galina I. Yermolenko (ed.): Roxolana in European Literature, History and Culture, Ashgate, 2010. 
di Solimano». ${ }^{36}$ Sagredo también ofrece una valoración de ambas explicando las rivalidades que aparecieron entre las dos consortes del sultán. Así pues, la Circassa se enemistó con Roxolana cuando esta adquirió un rango similar. La llamada Rossa, atrajo al Gran Turco con artimañas, lo sedujo con su belleza, con su piel perfumada, con sus gracias y lisonjas. A tal punto llegó la obsesión y el odio de la Circassa que llegado el día la golpeó, la despeinó y la arañó hasta desfigurarla. Ante los reproches de Solimán, Mahidrevran acusó a la favorita de tirana y de cruel. En cualquier caso, su actitud fue consecuencia de los celos al ver que el sultán se había rendido a los pies de otra mujer.

Quando s'avvide la Circassa, che l'altra gl'era fatta emula; che Solimano haveva per lei genio partiale, e che essa con arte studiata, e con odori, profumi, belletti, vezzi, e lusinghe tentava d'irretire l'affetto del Monarca, se gl'avvenò un giorno con empito, la battè, et essendo più di lei nerboruta, e forte, la scapigliò, la graffiò in modo, che la disfigurò. Mandò il Sultano per costei, volonteroso una notte di scapricciarsi seco; gli fece rispondere, che si trovava così male acconcia, che non era degna nè de'suoi sguardo, nè de'suoi affeti. Tanto maggiore fù a curiosità di vederla; e fattasela condurre innanzi la ricercò chi l'havesse così maltrattata: La Circassa, rispose, che è una Tiranna, che hà in abbominatione tutte quelle che stimano, e riveriscono il merito di Vostra Maestà. Non sò com il più umano, e il più clemente Principe di Casa Ottomana, goda di gettarsi sovente nel grembo di costei, che è quello della crudeltà stessa. ${ }^{37}$

En efecto, el texto pone de manifiesto el enfrentamiento que existió entre las dos damas por el amor del emperador pero sobre todo, en ellas anidaban intereses políticos que se veían amenazados con la presencia de la contraria. La Circassa y Roxolana combatían porque sus respectivos hijos llegasen a ser los herederos del trono. Por ello la ejecución de Mustafá, hijo de Solimán y Mahidrevran, se vinculó automáticamente a la figura de Roxolana, quien en realidad deseaba ver a su hijo Selim como futuro gobernador de los turcos y en consecuencia, ella misma convertirse en la madre del legítimo sucesor. Por ello, siguiendo el relato de la misma fuente escrita, observamos que Mustafá era el príncipe más aclamado por los otomanos. Se alababan sus cualidades militares pero mayormente se le consideraba un civil más, atrevido y discreto a la par. Era muy apreciado en la corte y en concreto para los jenízaros era un personaje digno de emular. Además, su buena fama le produjo ser objeto de profundas envidias y por este motivo Roxelana alentó su muerte, pues le deseaba enérgicamente la ruina y esperaba que sobre esta desgracia se posase el trono de su hijo. En su misión por acabar con el príncipe Mustafá, la elegida del Turco se ayudó de Rüstem Pasha o Rusten Bassa, el gran visir y marido de la hija de Solimán, Mirhimâh. Incitado por ellos, el sultán ordenó la búsqueda de su hijo y ante él, mandó estrangularlo con las cuerdas de un arco. Fallecer de 
este modo se entendía como una muerte triunfal digna de los príncipes. Según el relato, la caída de Mustafá fue consecuencia de su ambición e intención de conspirar contra su padre. Agudamente, el autor remarca la sed de poder del príncipe mediante un sugerente símil entre la codicia y el hambre. Para Sagredo la avaricia tiene la capacidad de despertar el apetito por reinar. De ser así, era necesario castigar la garganta y ahogar los deseos de poder. Por este motivo, se condenaba a morir por estrangulamiento.

Mustafa era il Primogenito. Non vide la Corte Ottomanica Principe di più alta espettatione. La nascita nulla tolse alla cortesia; la superbia nulla diede alla sua grandezza; Soldato, mà civile; ardito, e discreto. Egli era la delitia della Corte, l'Idolo de' Gianizzeri, l'ogetto de gl'applausi: Mà quanto più plaudito, tanto più invidiato, anzi insidiato da Rosolana, che cercava la sua rovina, perche sopra questa montaíse Selino suo figliolo al Trono. S'unì costei con Rusten Bassà, che havea per moglie una figliola del Rènata di lei, e unitamente machinarono al di lui esterminio. [...] Mandó per il figliolo, e fattolo condurre nel propio padiglione, lo fece strangolare da quattro muti alla sua presenza con la corda dell'arco. Simile morte è riputat da' Turchi più onoverole del ferro; e è quella, che si prattica co' Principi della Casa Reale, quasi che il passare per l'arco sia specie di morire in trionfo. Dicono, che essendo l'ambitione una fame, si leva à lei l'appetito di regnare collo strignere, e castigare la gola. Il di lui corpo fù esposto all'Armata, facendo gridare altamente per il Ministro, non esservi, che un Dio in cielo, e un Monarca in terra, imputandolo di cospiratione contra il Padre. ${ }^{38}$

Tras este análisis literario de la imagen de Roxolana o Hürrem y conocer la visión que se extendió sobre ella en Europa, cabe valorar algunas representaciones artísticas de este personaje de poder. Partimos de la hipótesis que sus imágenes no debieron ser tomadas del natural, pues la sultana no podía ser vista por los varones y, como se ha apuntado anteriormente, se trasladaba bajo un baldaquino para no mostrarse a los demás. Por tanto, su figura debió ser inmortalizada en las obras de arte a partir de los datos acerca de su origen y las descripciones sobre la indumentaria que llevaba. Existe un grabado de Mateo Pagan (s. XvI, Venecia) que refleja la efigie más conocida de la dama y presenta el bello aspecto de la sultana en el interior de un marco ovalado. Se trata de una imagen de busto y ladeada, en la cual la dama mira de reojo al espectador. Adquiere un mayor protagonismo el exótico traje, a la percepción occidental, que viste Roxolana. Las exquisitas galas se reproducen con todo lujo de detalles y están ornamentadas con joyas preciosas para crear una imagen de magnificencia. La inscripción visible en la parte inferior y central del grabado la identifica como la llamada Rossa, la más bella y la favorita del turco [Fig. 11]. Esta obra va pareja con la de su esposo, la cual sigue el modelo de representación que imperaba entre los retratos de los emperadores turcos,

38. SAgRedo, Memorie istoriche, pp. 342-343. 
es decir, una efigie de perfil para destacar la marcada fisionomía oriental y el exagerado turbante. Con un alto grado de probabilidad, la imagen de Pagan sobre Hürrem se puede vincular con la figura que aparece en Habiti antichi de Vecellio para plasmar a la predilecta del Gran Turco [Fig. 12]. En este caso, se mantiene la postura ligeramente ladeada que permite exponer en todo su esplendor el vestido que luce la dama. Una vez más, los rasgos faciales de la mujer no se han particularizado en el verdadero aspecto que debió tener Roxolana y por el contrario, se le otorga un mayor detallismo al diseño de la indumentaria. Las razones por las que el tratamiento del traje ha prevalecido sobre el físico son evidentes. Por un lado, el artista no había visto el rostro de la sultana, así que no era posible elaborar un retrato fiel a la apariencia de la dama. Y por otro lado, la existencia de catálogos de moda de la época, como el compendio de Vecellio, permitía vestir a la figura imaginada de la sultana con los fastuosos ropajes que la diferenciaban del resto de mujeres por su condición social y que además, ofrecían una visión realmente exótica para Occidente. En definitiva, el artista conseguía elaborar una imagen que exhibiese el lujo y el poder de la emperatriz mediante la imaginación y la inspiración en los libros de indumentaria.

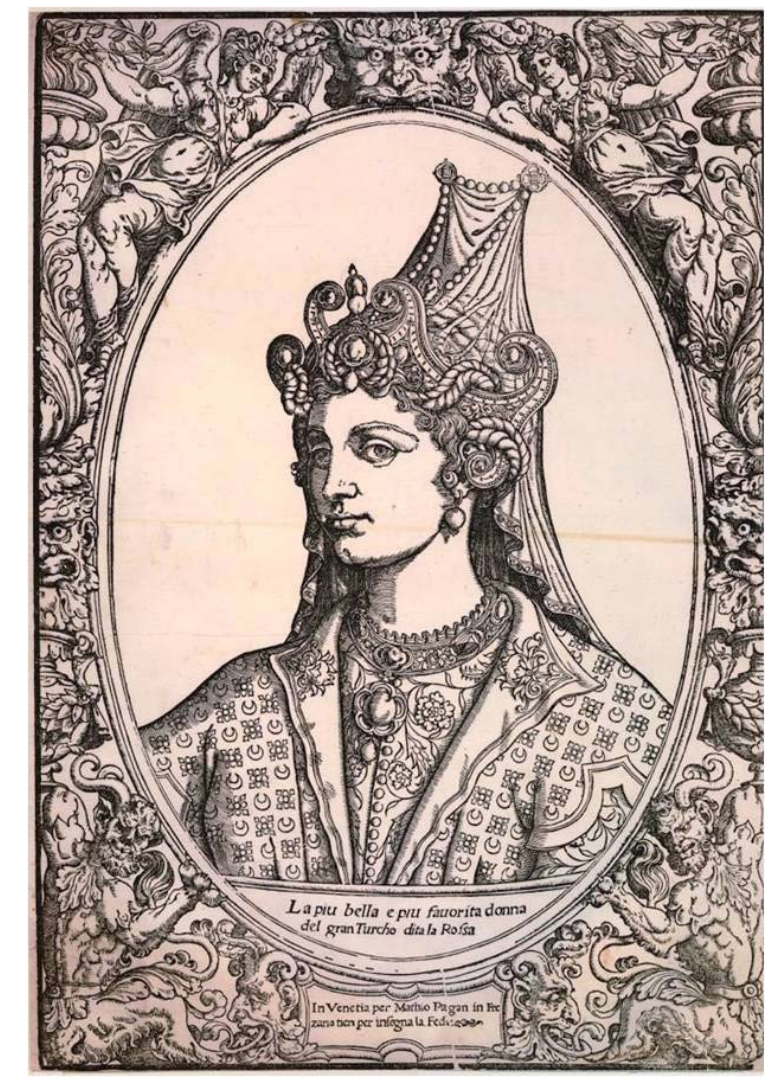

Fig. 11. Mateo Pagan, Roxolana o Hürrem, s. XVI, grabado, Venecia 


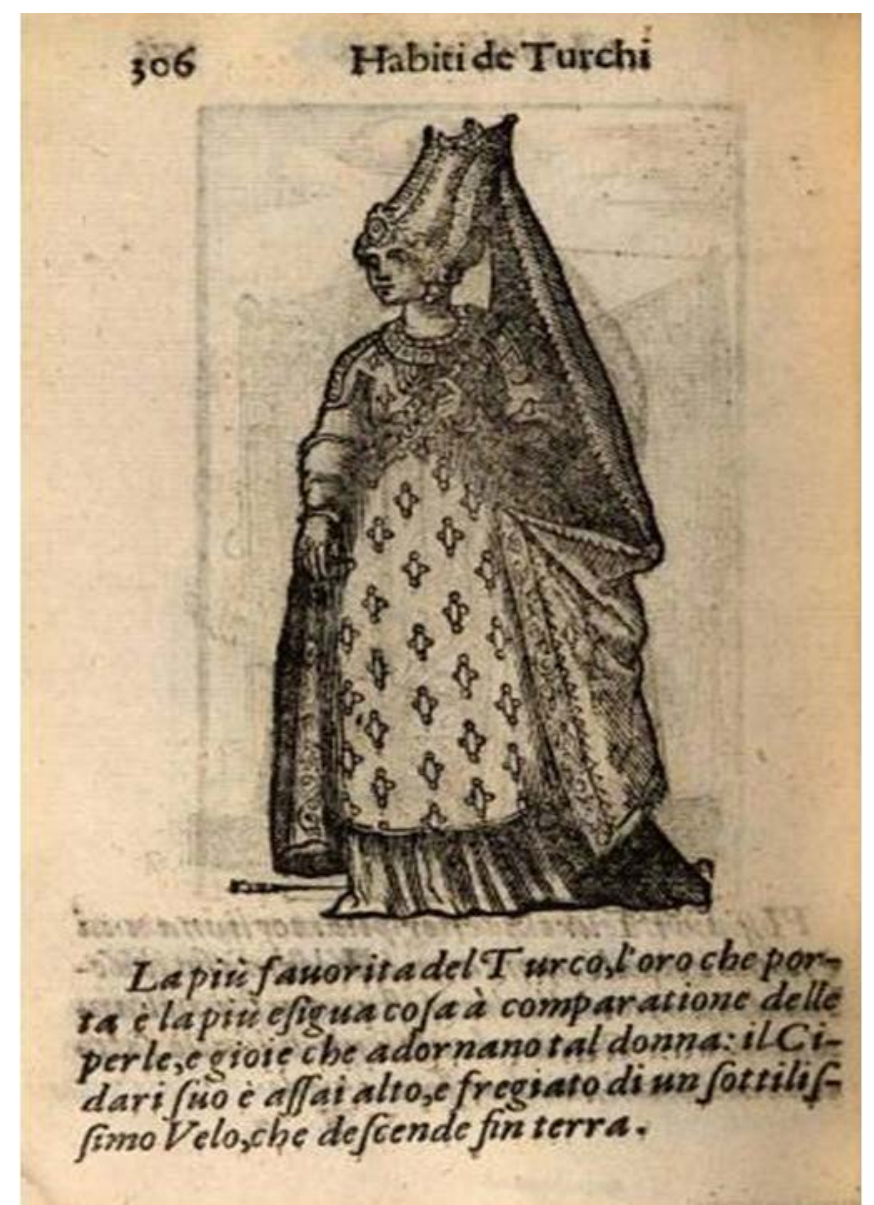

Fig. 12. Grabado de la favorita del Gran Turco en Cesare Vecellio, Habiti antichi, 1664, Venecia

Sin embargo, la vestimenta oriental no solo se recoge en los catálogos de moda y otros autores occidentales también han explicado brevemente el modo de vestir turco. Así lo hizo Jerónimo Román en uno de los capítulos de su libro Repúblicas. En dicha sección se encuentran referencias a los birretes altos que llevaban las mujeres, estos indicaban la categoría social de la señora según el grado de ornamentación que tuviesen.

Para ornamento suyo usan de cabello negro, y lo tienen por cosa de más gala, pero no lo hacen porque no conocen que el rubio es más conforme a la hermosura de las mujeres, más por no parecer en nada a las mujeres griegas cristianas que andan muy hermosas con los cabellos enrubiados, traen en las cabezas unos bonetes de raso muy apretado, y conforme es la mujer, así lo trae rico, o pobre, porque las grandes señoras lo traen de brocado, lleno de pedrería 
y perlas. Todo lo largo del cabello va colgado por las espaldas con una artificiosa compostura. ${ }^{39}$

Otra imagen coetánea es la famosa obra La sultana Rossa de Tiziano (s. XVI, Museo Ringlin, Estados Unidos) [Fig. 13]. Este retrato en concreto sí que se hace eco del origen nórdico de Hürrem y, en consecuencia, se presenta a la dama de tez blanquecina, cabellos claros y ondulados. Aparece ataviada con un rico vestido y el típico tocado alto, decorado con piedras preciosas, del cual nace un largo velo. Resulta sugerente que la elegida por el sultán y la considerada la más hermosa fuese una dama europea y su belleza no encajase con el prototipo de mujer turca. Asimismo, los autores occidentales menosprecian la belleza de las damas orientales e incluso afirman que sus almas no son puras, bondadosas o afectuosas, y por ello no son bellas.

En Oriente, lo que de lejos es bella perspectiva, es fealdad visto de cerca. Esta regla general puede aplicarse a las mujeres, lo mismo que a las ciudades. La mujer turca, de color moreno oscuro, carece de voluptuosidad en las formas, de gracias en los movimientos, de expresión en las miradas. Parece un ser sin voluntad ni conciencia, consecuencia lógica y fatal del estado abyecto en que vive. Hay en la mujer algo que la embellece, superior a su propia hermosura, algo que aparece en sus ojos y nos revela los sentimientos de un alma tierna, pura y cariñosa. Esa expresión infinita del semblante de la mujer es lo que falta en la mujer turca. Y así las más hermosas, no muchas, en honor de la verdad, ostentan una belleza sin sentimiento, una hermosura que nada dice. Para que no se nos eche en cara nuestra falta de galantería, dejamos a estas mujeres en su tristísimo estado de esclavas del hombre. ${ }^{40}$

Thèodore de Bry incluyó un maravilloso grabado de la sultana en la obra Vitae et icones sultanorum Turcicorum de Jean Jacques Boissard publicada en $1596{ }^{41}$ En ese mismo año, las cuarenta y siete imágenes de gobernantes se reprodujeron y el contenido se tradujo al alemán en Historia Chronologica Pannoniae: Ungarische und Siebenbürgische Historia de Johan Adam Lonicerus. En cualquier caso se dedican sendos capítulos a los personajes de Solimán y Roxolana precedidos por sus efigies. Estas fueron dibujadas por el artista flamenco Joris Hoefnagel y grabadas por Bry. Son representaciones de busto en formato de tres cuartos o completamente de perfil ubicadas en un medallón que a su vez se ha incrustado en un marco cuadrangular, todo ello se ha decorado con distintos elementos vegetales, insectos y aves, así como dos cartelas añadidas en la zona superior e inferior. Respecto al retrato de Hürrem, tenemos un nuevo ejemplo de la imagen más extendida de la favorita. De hecho, visualmente es posible relacionarla con la efigie encontrada en Vecellio o el

39. Román, Repúblicas, fol. 448 .

40. Moreno de la Tejera, Diario de un viaje a Oriente, p. 163.

41. Boissard, Vitae et icones sultanorum Turcicorum, p. 204. 


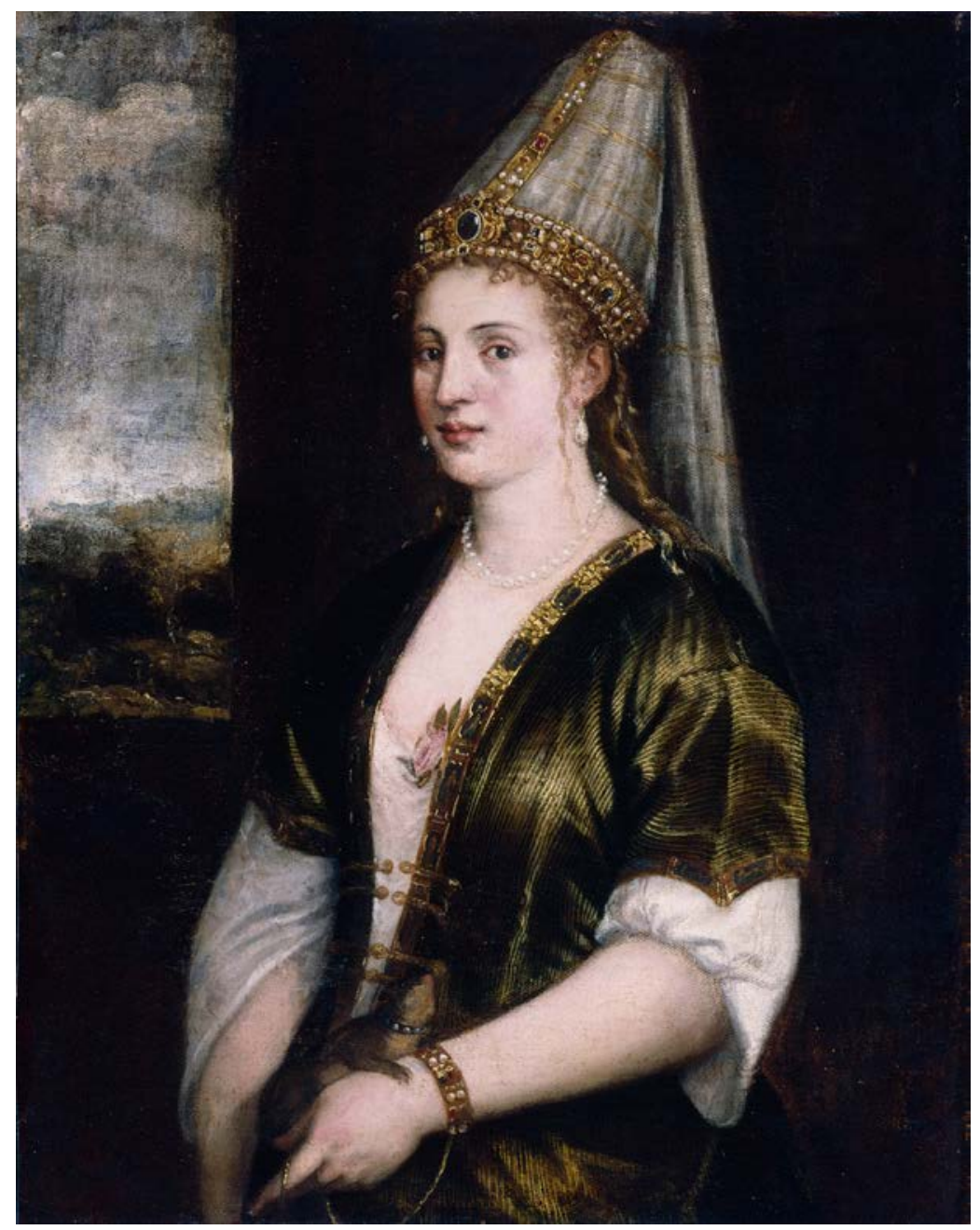

Fig. 13. Tiziano, La Sultana Rosa, s. XVI, óleo sobre lienzo, Museo Ringlin, Estados Unidos

diseño de Pagan, donde el elemento más destacable es el alto tocado repleto de perlas que la corona, del cual cae en cascada el largo velo. Alrededor de la figura femenina se ha insertado un breve texto latino para presentarla como la esposa de Solimán: Rossa Solimanni Uxor. Ello es realmente importante puesto que no estamos ante la haseki del sultán, sino que es la consorte legal del Gran Turco, la propia sultana. También es reseñable que la cartela superior se refiere a ella como una figura importante políticamente pero la tilda de tener un corazón cruel [Fig. 14]. Así pues, esta pieza sirvió de modelo para la elaboración de otros lienzos similares que especificarán el hecho de que sea la esposa de Solimán. 


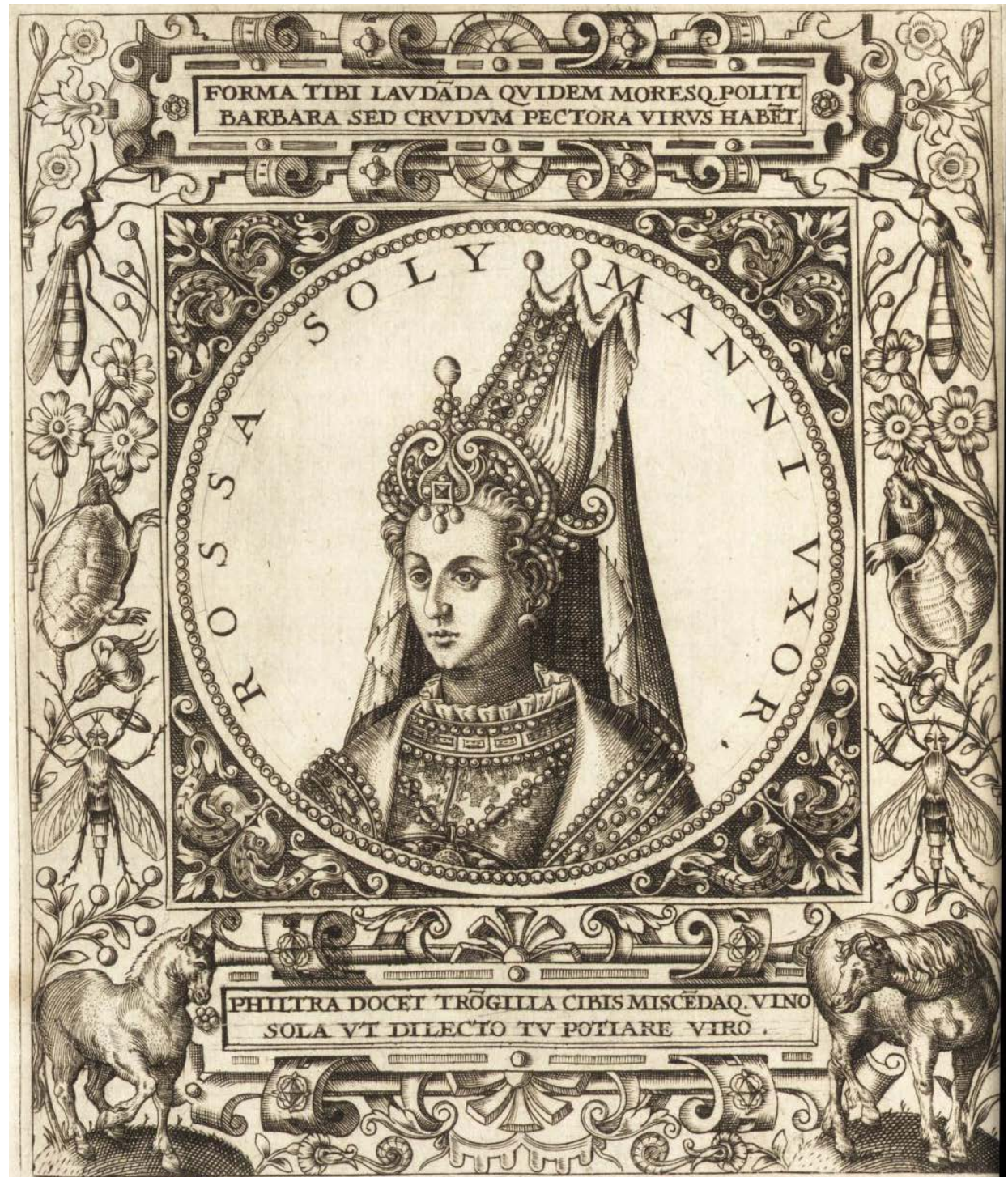

Fig. 14. Thèodore de Bry, Rossa Solimanni Uxor, en JeAn JACQues Boissard, Vitae et icones sultanorum Turcicorum, 1596

En consecuencia, las representaciones artísticas de Roxolana prueban que la imagen de poder de dicha mujer se ha codificado en un breve espacio de tiempo. En efecto, son abundantes los diseños que la presentan de busto o de medio cuerpo y exhibiendo la riqueza de su indumentaria oriental. En su conjunto, proyectan una apariencia un tanto idealizada, imaginada y creada en las mentes occidentales a partir de las informaciones de los viajeros que 
exploraban las tierras de Oriente y los catálogos de indumentaria que recogían el vestir de los diversos pueblos.

\section{Conclusiones}

Como hemos visto, los escritores y artistas de los siglos XVI y XVII consiguieron transmitir en textos e imágenes el poder del Imperio otomano. Para ello, principalmente se sirvieron de los relatos con el objetivo de identificarlos con la religión y, en definitiva, la cultura enemiga. Así pues, los calificaban de violentos y sanguinarios, e incluso pretendían exponerlos como una verdadera amenaza a la religiosidad europea matizando que todos los soldados del Gran Turco Solimán el Magnífico tenían raíces cristianas. Probablemente, en Oriente se veía como un triunfo del Islam tener la capacidad de nutrir un ejército con aquellos cristianos convertidos y sus descendientes. Igualmente es notoria la potestad adquirida por Hürrem o Roxolana, una mujer decidida y ambiciosa que hizo de sus propósitos, realidades. Llegó a ser sultana y empujó a su hijo Selim a ser el heredero de un gran imperio. Por sus raíces europeas y por ser la favorita de Solimán, las mentes imaginativas de Occidente contribuyeron a la creación visual y escrita de este personaje, hablando de sus diferencias con la Circassa, de sus planes para terminar con Mustafá y del dominio que alcanzó sobre el sultán. En cualquier caso, la magnificencia de los emperadores turcos resonó por toda Europa a través de la literatura y de las artes visuales, utilizando un lenguaje escrito y gráfico propio de los discursos de poder occidentales para no olvidar que el Gran Turco y su ejército hicieron tambalear los dominios de Carlos V. 